\title{
ANALISIS PERILAKU KONSUMEN KARTU GSM TELEPON SELULAR PADA PT. TELKOMSEL DI MALANG SEBAGAI DASAR PENETAPAN STRATEGI PERUSAHAAN
}

\author{
Boge Triatmanto \\ Fakultas Ekonomi Universitas Merdeka Malang
}

\begin{abstract}
This research observes the consumer behavior toward the usage of GSM card for cellular phone on PT. Telkomsel. Objectives of the research are to find out the consumer interest in using the GSM card on PT. Telkomsel and to find out the proper strategy which will be applied by PT Telkomsel in order to expand its market. The Observation is conducted on three areas: condition of the GSM-premiere card user, satisfaction level of the consumer and loyalty level of the consumer to the company products. This research uses internal and external environmental analysis that applying PLC, SWOT, and BCG analysis techniques. The research recommends that the company should, first, consider the internal as well as external factors which influence the consumer behavior in using the products of PT. Telkomsel Malang. Second, the company should determine the variation strategy in order to achieve optimal level of the consumer satisfaction. Third, it should determine a generic strategy, expansion, in order to achieve a well-known company of GSM card in Malang.
\end{abstract}

Key words : consumer behavior, SWOT analysis, generic strategy

Media komunikasi dan informasi berkembang pesat, peradaban modern yang merambah kemana-mana dan tuntunan jaman serta kehidupan masyarakat yang semakin maju, baik dari segi perubahan pandangan hidup, gaya hidup dan nilai-nilai yang dianut, maupun faktor-faktor psikologis yang menyangkut motivasi dan presepsi, maka sangat dibutuhkan alat penghubung (alat komunikasi) yang sesuai dengan tuntunan jaman tetapi tidak melanggar nilainilai yang dianut oleh masyarakat.

Saat ini telepon selular sudah bukan merupakan barang langka yang sangat mahal dan sulit didapatkan, tetapi sudah merupakan barang kebutuhan sehari-hari, terutama dikota-kota besar, terlebih bagi mereka yang beraktivitas didunia bisnis yang kehidupan bermasyarakatnya sangat menghargai waktu, cara hidup yang praktis dan efisien. Informasi dan komunikasi harus terus berjalan lancar, walaupun kesibukannya sangat padat. Diharapkan pula dengan 
menggunakan telepon selular tersebut dapat lebih mendukung kesuksesan pekerjaannya dan waktu dipergunakannya dapat lebih dipersingkat karena kemudahan dalam berhubungan atau berkomunikasi lewat telepon selular tersebut. Agar telepon selular tersebut dapat berfungsi atau menjalankan operasionalnya dengan baik, selain dibutuhkan manusia sebagai pengguna juga dibutuhkan kartu atau chip yang dapat berfungsi untuk menjalankan sistem yang terdapat pada telepon selular tersebut.

Ada beberapa perusahaan yang memproduksi telepon selular. Banyaknya telepon selular diikuti pula oleh banyaknya perusahaan kartu dari telepon selular tersebut. Salah satunya adalah PT. Telekomunikasi Selular (Telkomsel) yang berkududukan pusat di Jakarta. PT. Telkomsel mempunyai beberapa service centre yang beroperasional dibeberapa daerah di Indonesia. PT.Telkomsel Malang adalah merupakan salah satu dari sekian service centre yang ada di berbagai daerah tersebut.

Salah satu faktor utama bagi perusahaan agar mampu bersaing untuk menarik konsumen adalah dengan meningkatkan mutu pelayanannya dan juga fasilitas produknya. Agar dapat meningkatkan mutu dan pelayanannya maka seyogyanya perusahaan harus mengetahui prilaku konsumen secara mendalam, kecenderungan serta faktor-faktor yang mempengaruhinya untuk selanjutnya perusahaan harus dapat mengantipasi dan menindak lanjuti terhadap perubahan dari perilaku komsumen tersebut dan selanjutnya dapat menyusun strategi kedepan bagi perusahaan. Karena perusahaan yang berhasil mencapai tujuannya adalah perusahaan yang mempunyai dan konsisten dengan visi, misi dan tujuannya untuk dapat menentukan strategi, baik terhadap konsumen maupun untuk menghadapi pesaing dan perusahaan yang berorientasi pada konsumen.

Dalam mencapai target, baik jangka panjang maupun jangka pendek dan untuk dapat menyusun strategi ke depan agar perusahaan dapat terus eksis dalam usahanya maka perusahaan harus mengadakan penelitian terhadap perubahaan lingkungan baik secara langsung maupun tidak langsung yang dapat mempengaruhi kehidupan ekonomi serta perilaku masyarakat. Perubahan pada perilaku konsumen akan berpengaruh terhadap keputusan dalam mengadakan pemilihan terhadap produk apa yang akan digunakan. 
Tujuan penelitian ini antara lain untuk mengetahui minat konsumen dalam menggunakan kartu GSM telpon selular pada PT. Telkomsel di Malang dan untuk mengetahui, strategi apa yang akan digunakan oleh PT. Telkomsel di Malang untuk mencapai perluasan pasar.

\section{PERILAKU KONSUMEN}

Perilaku konsumen menurut Basu Swastha (1987 : 9) adalah:

“Perilaku konsumen adalah kegiatan-kegiatan individu yang secara langsung terlibat dalam mendapatkan dan mempergunakan barang dan jasa termasuk didalamnya proses pengambilan keputusan dan persiapan serta penentuan kegiatan tersebut".

Menurut pendapat Winardi (1991 : 49) adalah:

“Perilaku konsumen adalah perilaku yang ditunjukkan oleh orang-orang dalam hal merencanakan membeli dan menggunakan barang-barang ekonomi dan jasa". Sofyan Assauri (1992 : 124) mengatakan: "Perilaku konsumen merupakan keputusan seseorang untuk melaksanakan pembelian merupakan hasil perhitungan ekonomis rasional yang memberikan kegunaan yang paling besar sesuai dengan selera dan biaya yang relatif".

Secara umum dari pendapat para ahli tersebut dapat disimpulkan bahwa perilaku konsumen adalah tindakan-tindakan yang dilakukan oleh individu, kelompok atau organisasi yang berhubungan dengan proses pengambilan keputusan dalam mendapatkan, menggunakan barang-barang atau jasa ekonomis dan kegiatan pengembalian keputusan tersebut dapat dipengaruhi lingkungan. Jadi, analisis perilaku konsumen yang realitas hendaknya harus menguraikan proses-proses yang tidak dapat atau sulit diamati, yang selalu menyertai setiap pembelian. Salah satu faktor yang banyak berperan dan banyak mendapat sorotan dari masyarakat adalah faktor psikologis. Telaah-telaah psikologis menunjukkan bahwa kegiatan manusia termasuk didalamnya perilaku konsumen diarahkan pada pemuasan kebutuhan-kebutuhan.

Para konsumen akan membandingkan jumlah pendapatan yang diterima dengan anggaran belanja terhadap macam-macam barang yang disesuaikan dengan kemampuannya. Masyarakat kita terbagi menjadi tiga golongan berdasarkan pendapatan, walaupun sangat relatif sifatnya, yaitu : masyarakat berpenghasilan tinggi, masyarakat berpenghasilan menengah dan masyarakat berpenghasilan rendah. 
Masing-masing kriteria sulit dibedakan secara tepat berapa jumlah penghasilannya karena pengamatan serta pendapat seseorang sangatlah berbeda. Pola konsumsi masyarakat dapat dilihat dari penghasilan yang diterima walaupun tidak dapat dijadikan ukuran mereka termasuk kelompok yang mana karena sifatnya relatif sekali, konsumen akan lebih mudah mengambil keputusan pada pembelian ulang terhadap produk yang sama atau yang sifatnya terus-menerus (dalam harga dan kualitasnya).

\section{Faktor-Faktor yang Mempengaruhi Perilaku Konsumen}

Menurut Basu Swastha (1987 : 56 - 57) mengenai faktor-faktor yang mempengaruhi perilaku konsumen adalah : Perilaku seseorang dipengaruhi oleh faktor lingkungan dimana orang itu berada sehingga keinginan antara orang yang satu dengan yang lainnya berbeda. Perilaku konsumen sangat dipengaruhi berbagai lapisan masyarakat dimana dia dilahirkan dan dibesarkan. Ini berarti seseorang yang berasal dari lapisan masyarakat atau lingkungan yang berbeda akan mempunyai penilaian kebutuhan pendapatan, sikap dan selera yang berbeda.

Adapun beberapa faktor yang mempengaruhi perilaku konsumen menurut Basu Swastha (1987 : 15) ada dua variabel, yaitu faktor-faktor ekstern yang mempengaruhi perilaku konsumen (kelas sosial, kelompok sosial dan kelompk referensi, keluarga) dan faktor-faktor intern atau individu yang menentukan perilaku (pendapatan, pelayanan, harga, promosi, lokasi, produk).

Proses pengambilan keputusan oleh konsumen berbeda-beda menurut jenis keputusan pembelian keputusan yang lebih kompleks mungkin melibatkan partisipasi yang lebih banyak dan kebebasan pembeli yang besar. Menurut Kotler (1991 : 199-201) ada tiga jenis perilaku pembelian, antara lain pertama, perilaku tanggapan rutin, Jenis perilaku yang paling sederhana, terjadi kalau konsumen membeli barang atau jasa yang murah dan sering dibeli. Kedua, pemecahan masalah terbatas Pembelian akan lebih kompleks jika pembelian tidak mengetahui sebuah merk dalam suatu jenis produk yang disukai sehingga membutuhkan informasi lebih lagi sebelum memutuskan membeli. Ketiga, penyelesaian masalah ekstensif, suatu pembelian akan menjadi sangat kompleks, 
jika pembeli menjumpai jenis produk yang kurang dipahami dan tidak dimengerti kriteria penggunaannya.

\section{STRATEGI BERSAING GENERIK}

Strategi bersaing adalah tindakan ofensif atau difensif untuk menciptakan posisi yang aman (defendable) dalam industri. Ada tiga strategi generik, pertama, keunggulan posisi biaya rendah akan membuat perusahaan mendapatkan hasil laba diatas rata-rata dalam industrinya, meskipun ada kekuatan persaingan yang besar. Posisi biayanya akan memberikan kepada perusahaan tersebut ketahanan terhadap rivalitas dari para pesaing, karena biayanya yang rendah memungkinkan mengorbankan laba mereka demi persaingan. Posisi biaya rendah biasanya menempatkan pada perusahaan pada posisi yang menguntungkan dalam menghadapi produk pengganti relatif terhadap posisi para pesaingnya dalam industri. Strategi biaya rendah mungkin memerlukan investasi modal pendahuluan yang besar untuk membina bagian pasar. Bagian pasar yang tinggi pada akhirnya dapat memugkinkan skala ekonomis dalam pembelian yang semakin menekan biaya. Jika tercapai, posisi biaya rendah memberikan margin tinggi yang dapat diinvestasikan kembali untuk peralatan baru dan fasilitaas yang modern guna mempertahankan keunggulan biaya. Investasi kembali seperti itu merupakan prasyarat untuk mempetahankan posisi biaya rendah.

Kedua, diferensiasi yaitu menciptakan sesuatu yang baru dirasakan oleh keseluruhan industri sebagai hal yang unik. Pendekatan untuk melakukan diferensiasi dapat bermacam-macam bentuknya, misalnya citra rancangan atau merk, karakteristik khusus pelayanan pelanggan, jaringan penyalur, dan lainlain. Tetapi idealnya perusahaan mendiferensiasikan dirinya dalam beberapa dimensi. Diferensiasi memberi penyekat terhadap persaingan karena adanya loyalitas merk dari pelanggan dan mengakibatkan berkurangnya kepekaan terhadap harga. Diferensiasi juga meningkatkan margin laba dan yang menghindarkan kebutuhan akan posisi biaya rendah. Tetapi tidak semua pelanggan mampu atau mau membayar harga yang lebih tinggi. Dalam bisnisbisnis lain diferensiasi mungkin tidak sesuai dengan biaya yang relatif rendah dan dengan hanya yang sebanding yang disajikan pesaing. 
Ketiga, Fokus yaitu memusatkan pada kelompok pembeli, segmen lini produk, atau pasar geografis tertentu. Seperti halnya diferensiasi, fokus dapat bermacam-macam bentuknya. Fokus dibangun untuk melayani target tertentu secara baik. Strategi ini didasarkan pada pemikiran bahwa perusahaan dengan demikian akan mampu melayani target strategisnya yang sempit secara efektif dan efisien dibanding pesaing yang bersaing lebih luas. Sebagai akibatnya, perusahaan akan mencapai diferensiasi karena mampu memenuhi kebutuhan target tertentu dengan lebih baik, atau mencapai biaya yang lebih rendah dalam melayani target ini, aau bahkan mencapai kedua-duanya. Strategi ini sesungguhnya mencapai salah satu atau kedua posisi tersebut ditarget pasarnya yang lebih sempit. Perbedaan diantara strategi ini digambarkan dalam gambar sebagai berikut:

\section{ANALISIS SWOT}

Menurut Amien Widjaja Tunggal (1996:74-75) SWOT adalah akronim untuk kekuatan (strengths) dan kelemahan (weaknesses) internal suatu perusahaan serta peluang (opprotunities) dan ancaman (threats) lingkungan yang dihadapi perusahaan. Analisa SWOT merupakan identifikasi yang sistematis dari faktorfaktor ini dan dari strategi yang menggambarkan pedoman yang terikat antara mereka yakni untuk mengetahui posisi perusahaan pada saat ini dan mendatang atau dengan kata lain diperlukan untuk menentukan strategi dan taktik perusahaan agar mawas diri dan tahu diri dalam memasuki dunia usaha yang bersaing.

Faktor dasar dari analisa SWOT antara lain pertama, kekuatan (strengths) adalah sumber daya, ketrampilan dan keunggulan lain relatif terhadap pesaing dan pasar yang dimiliki suatu perusahaan. Karena kekuatan merupakan suatu kompetensi yang berbeda dan memberikan perusahaan suatu keunggulan komparatif dalam pasar. Kekuatan berkaitan dengan sumber daya keuangan, citra, kepemimpinan pasar hubungan pembeli/ pemasok dan faktor-faktor lain.

Kedua, kelemahan (weaknesses) merupakan keterbatasan/kekurangan dalam sumber daya, ketrampilan dan kemapuan yang secara serius menghalangi kinerja efektif suatu perusahaan. Ketiga, peluang (opportunities) merupakan situasi yang menguntungkan dalam lingkungan eksternal perusahaan. 
Kecenderungan-kecenderungan utama merupakan salah satu dari peluang dapat berupa indentifikasi dari sekmen pasar yang sebelumnya terlewatkan, perubahan-perubahan dalam keadaan bersaing akan peraturan perubahan teknologi dan hubungan pembeli dan pemasok yang diperbaiki dapat menunjukkan peluang bagi perusahaan.

Keempat, ancaman (threats) adalah situasi utama yang tidak menguntungkan dalam lingkungan suatu perusahaan. Ancaman adalah rintangan-rintangan utama bagi posisi sekarang atau yang diinginkan oleh perusahaan. Masuknya pesaing baru, pertumbuhan pasar yang lambat, daya tawar pembeli dan pemasok utama yang meningkat, perubahan teknologi dan peraturan yang baru atau yang direvisi dapat merupakan ancaman bagi keberhasilan perusahaan.

Menurut Glueck (1994 : 208) dengan membandingkan ETOP dan SAP akan ditemukan petunjuk tentang alternatif strategi untuk menutupi kesenjangan. Jika terdapat peluang lingkungan yang besar dengan kemampuan intern untuk mendapatkan manfaat daripadanya, maka alternatif ekspansi mungkin dilakukan. Kalau ancaman lingkungan kelihatannya merupakan tekanan terberat, maka mungkin cara untuk meningktkan potensi harga ialah dengan penciutan. Kalau tidak terdapat kesenjangan (atau kesenjangan tidak penting, atau yakin bawa kesenjangan itu masih dapat dikendalikan) memungkinkan untuk mengejar pendekatan yang mantap (stabilitas).

\section{METODE}

Penelitian ini merupakan penelitian deskriptif yang bermaksud untuk menganalisis perilaku konsumen dalam menentukan strategi perusahaan. Variabel-variabel dalam penelitian ini antara lain: perilaku konsumen yang terdiri dari faktor intern dan ekstern. Faktor intern antara lain pertama motivasi, yaitu kompleksitas motif masing-masing individu untuk memenuhi kebutuhannya. Item-itemnya adalah kebutuhan fisologis konsumen, kebutuhan untuk meningkatkan kreatifitas konsumen, kebutuhan akan harga diri dalam masyarakat (prestise), kebutuhan rasa ingin memiliki telepon selular.

Kedua, persepsi yaitu proses penerimaan atau reaksi orientatif individu (konsumen) terhadap rangsangan-rangsangan (terhadap panca indera) yang 
berasal dari lingkungan intern dan ekstern. item-itemnya adalah melihat kenyamanan dan kompleksitas pemakaian telepon selular.

Ketiga, proses belajar yaitu perubahan-peubahan perilaku yang terjadi sebagai akibat adanya pengalaman yang terjadi dengan adanya interaksi dengan lingkungannya. item-itemnya adalah pengalaman pembelian kartu telepon selular dimasa lalu, kebiasaan dalam membeli kartu selular, dan pengalaman orang lain.

Keempat, sikap yaitu keadaan jiwa (mental) dan keadaan fikir (neural) yang di persiapkan untuk memberikan tanggapan terhadap suatu obyek yang diorganisir melalui pengalaman serta mempengaruhi secara langsung dan atau secara dinamis pada perilaku konsumen. Item-itemnya adalah tingkat kemampuan secara fisik konsumen dalam membeli kartu telepon selular, kemampuan secara mental dalam membeli jenis kartu selular, kemampuan konsumen untuk menerima keberadaan suatu jenis kartu telepon selular, kemampuan konsumen untuk menerima keberadaan jenis kartu telepon selular.

Kelima, kepribadian, yaitu pola sifat konsumen yang dapat menentukan tanggapan dan cara untuk bertingkah laku. Item-itemnya pengetahuan dari konsumen yang mendasari dalam bertingkah laku, perasaan dari hasil pengaruh pengetahuan, dorongan untuk meniru orang lain dalam berperilaku.

Keenam, konsep diri yaitu cara seseorang memandang dirinya sendiri dengan tujuan untuk membandingkan antara deskripsi konsep diri konsumen yang ditunjukkan sendiri dengan konsep diri yang dibuat. Item-itemnya adalah merk kartu telepon selular apakah yang paling disukai oleh masing-masing konsumen, dengan penjual manakah konsumen tersebut berhubungan, kemampuan konsumen dalam menerima keberadaan periklanan.

Faktor ekstern yaitu faktor-faktor yang mempengaruhi konsumen dalam berperilaku berasal dari lingkungan dimana konsumen dilahirkan dan dibesarkan atau dapat dikatakan faktor-faktor yang mendorong konsumen melakukan pembelian. Variabel-variabel faktor ekstern ini antara lain : pertama, keluarga, yaitu kelompok yang pertama kali membina sikap dasar seseorang, dimana keluarga mempunyai peranan yang besar terhadap keputusan. Itemitemnya adalah ayah, ibu, dan anak. 
Kedua, kelas sosial yaitu pembedaan masyarakat kedalam kelas-kelas secara bertingkat. Item-itemnya adalah kekayaan, jabatan, penghargaan dan ilmu pengetahuan atau tingkat pendidikan. Ketiga, kelompok panutan yaitu kelompok dalam dimana orang ingin menjadi anggota atau dimana orang ingin mengidentifikasikan dirinya. Item-itemnya adalah pengaruh rekan sekerja, pengaruh perkumpulan atau organisasi dimana konsumen menjadi anggota.

Keempat, kebudayaan yaitu simbul dan fakta yang kompleks, diturunkan dari generasi ke generasi sebagai penentu dan pengatur perilaku manusia dalam masyarakat yang ada. Item-itemnya adalah adat istiadat, nilai-nilai sosial yang berlaku di masyarakat, norma-norma sosial yang diterapkan di masyarakat, agama. Kelima, perilaku individu yaitu proses pengambilan keputusan untuk membeli kartu telpon selular menurut tahapan-tahapan rasional.

Strategi perusahaan merupakan pola dari berbagai tujuan serta kebijakan dasar dan rencana-rencana untuk mencapai tujuan yang dirumuskan sedemikian rupa sehingga jelas usaha apa yang akan dilaksanakan oleh perusahaan. Dalam menjalankan strategi untuk mengandalkan keunggulan bersaing dalam membangun kepuasan konsumen perlu dinyatakan secara tertulis dan dikomunikasikan secara meluas, sehingga tidak seorangpun meragukan apa yang akan dirancang dan dicapainya. Hal tersebut perlu diimbangi dengan struktur organisasi yang dirancang untuk tanggapan pelanggan.

Teknik analisis digunakan dalam penelitian ini adalah analisis deskriptif, yaitu Menganalisis dari hasil perolehan data dari lapangan kedalam sebuah laporan, agar didapat gambaran secara menyeluruh tentang kepuasan pelanggan terhadap pelayanan PT.Telkomsel. Alat yang dipakai dalam analisis ini adalah analisis PLC (Product Life Cycle), SWOT, dan BCG sebagai strategi pemasaran.

\section{HASIL DAN PEMBAHASAN}

\section{Hasil}

\section{Analisis PLC (Product Life Cycle)}

Analisis ini dimaksudkan untuk mengetahui aktivitas perusahaan khususnya didalam usaha peningkatan mutu pelayanan secara menyeluruh baik ditinjau secara ekstern maupun intern perusahaan. Setelah dilakukan analisis secara menyeluruh, pada akhirnya akan diketahui bagaimana pelaksanaan 
metode pelayanan yang selama ini dijalankan, sekaligus memberi input terhadap strategi di dalam meningkatkan mutu pelayanan konsumen pada PT. Telkomsel.

Tahap Perkenalan. Pada tahap perkenalan, produk kartu selular PT.Telkomsel, baik kartu Pra Bayar maupun Pasca Bayar menempuh masa perkembangan. Masa perkembangan tersebut mencakup tahap pemasaran uji coba di kota Malang, namun belum mengalami peluncuran secara besar-besaran.

Tahap Pertumbuhan. Dalam perkembangan selanjutnya produk yang baru diluncurkan tersebut dapat memuaskan pembeli. Golongan inovator dini melanjutkan pembelian, dan sejumlah besar konsumen yang konvensional mengikuti teladan mereka terutama setelah ada cerita orang yang menguntungkan perusahaan, maka produk diperluas pasarnya. Permintaan semakin banyak dan meningkat, karena di era teknologi sekarang, handphone adalah salah satu kebutuhan, didukung oleh gaya hidup masyarakat sekarang yang dinamis. Pada tahap pertumbuhan ini kartu selular GSM mempunyai beberapa macam produk, Pasca Bayar (Kartu Halo) dan Pra Bayar (Simpati dan Kartu As, serta varian lain dari kedua produk tersebut). Dilihat dari tingkat kepuasan konsumen terhadap produk kartu selular GSM Pasca Bayar (Kartu Halo), meningkat dengan pesat. Tetapi setelah diluncurkan kartu selular GSM Pra Bayar nomor Malang, maka kartu Pasca Bayar (Kartu Halo) mulai memasuki tahap kedewasaan. Sedangkan kepuasan konsumen terhadap perusahaan secara keseluruhan mengalami pertumbuhan yang tinggi. Hal tersebut terlihat dari tabel penilaian tingkat kepuasan konsumen terhadap profil perusahaan dan tabel tingkat loyalitas konsumen terhadap PT. Tekomsel.

Tahap Kedewasaan. Pada suatu saat titik laju pertumbuhan penjualan akan menjadi lamban, dan produk akan memasuki tahap kedewasaan. Pada fase ini kartu selular GSM Pasca Bayar memasuki fase kedewasaan yang mantap, yang pada saat volume penjualan mulai mendatar atas dasar perkapita. Hal ini disebabkan oleh kejenuhan pasaran dan sebagian pelanggan mulai beralih pada produk pengganti lainnya yaitu Pra Bayar (Simpati Nusantara).

Tahap Kemerosotan. PT. Tekomsel secara keseluruhan belum mengalami tahap ini. Berdasarkan analisis PLC tersebut dapat digambarkan sebagai berikut: 


\section{Gambar 1}

Produk Life Cycle

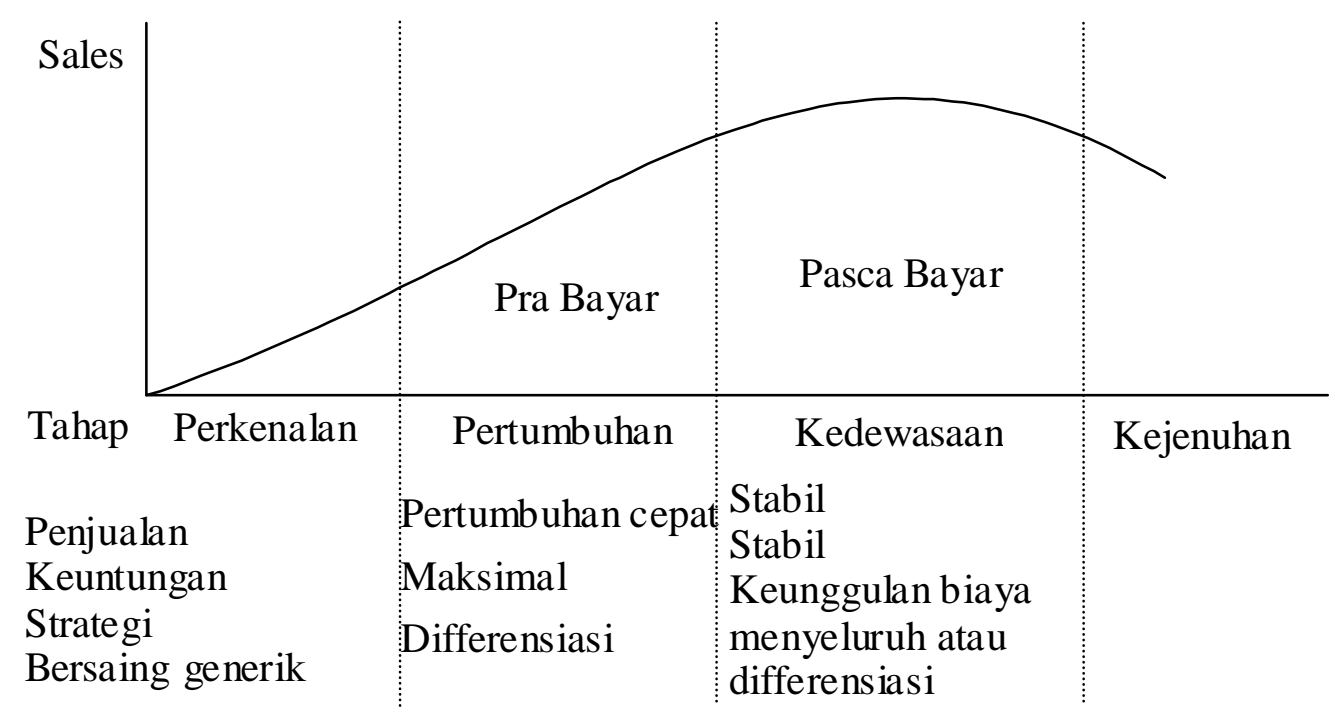

Dari gambar diatas dapat ditentukan strategi bersaing generik yang dapat dilakukan perusahaan untuk menciptakan posisi yang aman dalam industri.

Pada produk kartu selular GSM Pasca Bayar dapat digunakan strategi bersaing generik keunggulan biaya menyeluruh dan diferensiasi, sedangkan produk kartu selular GSM Pra Bayar dapat menggunakan strategi bersaing generik diferensiasi.

Strategi bersaing generik tersebut, antara lain pertama, Strategi keunggulan biaya menyeluruh. Posisi biaya yang rendah memugkinkan untuk tetap dapat menghasilkan laba, jika tercapi posisi, biaya rendah memberikan margin tinggi yang dapat diinvestasikan kembali untuk peralatan baru dan fasilitas yang modern guna mempertahankan keunggulan biaya. PT.Telkomsel selalu berusahan melakukan inovasi, pada produknya agar selalu menjadi yang terdepan dalam teknologi kartu selular GSM di Indonesia.

Kedua, Strategi diferensiasi. PT.Telkomsel melakukannya dengan citra rancangan atau merk, Kartu Pasca Bayar merupakan kartu selular GSM yang mempunyai daya jangkau yang sangat luas bahkan sampai dunia internasonal dengan tidak mengurangi kenyamanan berkomunikasi sedangkan Pra Bayar sangat efisien digunakan di seluruh wilayah nusantara dengan kenyamanan komunikasi dimanapun pelanggan berada, cukup mencakup membuat 
pelanggan selau loyal dengan produk dari PT.Telkomsel. Karakteristik khusus pelayanan pelanggan, dengan sistem pembayaran yang sangat praktis dan memudahkan pelanggan ditambah dengan fasilitas-fasilitas yang ada pada kartu selular GSM PT.Telkomsel serta layanan purna jual dan media promosi yang kontinyu membuat pelanggan merasa kebutuhan akan komunikasi yang praktis menjadi terpenuhi. Jaringan penyalur yang tersebar luas memudahkan konsumen dalam mendapatkan produk.

\section{Analisis SWOT}

Analisi Internal (Strategic, Advantage, Profile/ SAP), Strenght (kekuatan), Faktor yang dipandang sebagai kekuatan bagi PT. Telkomsel antara lain Telkomsel merupakan perusahaan kartu selular GSM terkemuka di Indonesia sehingga terpercaya. Hal ini merupakan kelebihan yang dimiliki oleh PT.Telkomsel, karena dengan demikian konsumen cenderung untuk lebih memilih menggunakan produk kartu selular GSM dari PT. Telkomsel. Hal ini juga ditunjang dengan tingkat pelayanan yang memadai, sehingga diharapkan akan menambah dan memaksimalkan perolehan keuntungan.

Sumber daya manusia yang dimiliki oleh PT.Telkomsel dilihat dari segi pendidikan dan dedikasi yang tinggi dari para karyawan akan sangat mendukung kemajuan perusahaan. Media promosi sangat bagus, menunjukkan bahwa produk dari Telkomsel sangat berkualitas dan dapat digunakan diseluruh panjuru nusantara. Hal ini sangat diperlukan guna mempertahankan posisi market leader,mengingat sekarang ada beberapa pesaing bagi PT.Telkomsel.

Layanan purna jual kartu selular GSM PT.Telkomsel yang memuaskan. Luasnya daya jangkau dari kartu selular GSM PT.Telkomsel, sehingga memungkinkan setiap orang berkomunikasi dimanapun dia berada, baik diseluruh nusantara maupun diluar negeri. Keadaan keuangan perusahaan yang stabil dan cenderung meningkat dikarenakan semakin meningkatnya permintaan konsumen akan kartu selular GSM.

Kelemahan (Weakness), yang merupakan hasil analisis kelemahan adalah Distribusi untuk kartu Simpati yang agak terhambat sampai ke tangan konsumen yang harus melalui beberapa tangan terlebih dahulu dan dengan harga yang sudah diatas standart, dikarenakan kelangkaan produk. 
Analisis Eksternal (Environtment, Trade, opportunity, Profit/ETOP). Opportunity (peluang), hal yang menjadikan peluang bagi perusahaan antara lain Malang merupakan kota aktif yang potensial, Malang merupakan kota besar kedua di Jawa Timur yang memiliki tingkat kesibukan yang tergolong sangat tinggi, dimana perputaran yang sangat cepat dan terdiri dari masyarakat yang beragam dengan berbagai kesibukannya masing-masing. Kondisi seperti ini sebaiknya benar-benar lebih bisa diupayakan untuk dapat memasuki pasar dari konsumen yang beragam. Dengan dapat menjalin kerjasama dengan berbagai instansi-instansi maupun lembaga pendidikan dan sebagainya, diharapkan dapat meningkatkan usaha.

Tingkat sosial ekonomi masyarakat rata-rata baik. Kita lihat secara sepintas bahwa tingkat sosial ekonomi masyarakat Malang rata-rata stabil dan memiliki kemampuan di dalam mengkonsumsi produk dari PT.Telkomsel.

Pengetahuan masyarakat akan manfaat kemudahaan komunikasi semakin bertambah. Kondisi sekarang dengan kondisi dulu berbeda pada saat ini masyarakat telah mengetahui manfaat komunikasi. Berbeda dengan kondisi dulu, dimana masyarakat masih merasa asing dan tidak mengetahui manfaat dan mendapatkan kemudahaan komunikasi jarakjauh.

Demografi, dengan adanya angka pertambahan penduduk dari tahun ke tahun yang cukup tinggi, maka mengakibatkan kebutuhan akan komunikasi yang mudah dan praktis yang dapat menghemat waktu, tenaga, dan uang.

Kemajuan Teknologi PT. Telkomsel. dengan adanya teknologi maju yang dimiliki oleh PT.Telkomsel, memungkinkan fasilitas-fasilitas yang terdapat pada kartu selular GSM PT.Telkomsel selalu selangkah lebih maju dibandingkan perusahaan sejenis lainnya.

Treath (ancaman), yang menjadi ancaman bagi perusahaan antara lain, Pesaing, dengan melihat bahwa Malang merupakan pasar yang sangat potensial, maka hal ini menimbulkan beberapa perusahaan kartu selular GSM sama-sama bersaing memperebutkan pasar. Pihak PT. Telkomsel lebih mampu dalam menunjukkan keunggulan yang dimiliki dibanding pesaingnya kepada konsumen dengan terus meningkatkan mutu pelayanan.

Kondisi negara terutama perekonomian yang masih belum stabil. Kondisi perekonomian negara yang kurang stabil mempengaruhi penggunaan 
penutupan atau tidak digunakannya lagi kartu selular di masyarakat. Oleh karena itu perusahaan harus mampu mempertahankan target penjualan dengan cara melakukan pendekatan-pendekatan kepada para pemegang kartu seluler GSM tersebut.

Semakin selektif calon konsumen dalam memilih perusahaan kartu seluler GSM. Kondisi ini harus sangat diperhatikan jangan sampai karena PT. Telkomsel sudah mempunyai image yang baik, maka dalam mutu pelayanan, baik pra jual maupun purna jual diabaikan. Perlu juga adanya kontrol sewaktuwaktu, baik terhadap produk maupun pemasarannya agar service marketing selalu terlaksana dengan baik.

Image masyarakat terhadap kartu selular. Masih banyaknya masyarakat yang menganggap komunikasi tidak begitu penting, hal ini berbanding terbalik dengan masyarakat modern di negara-negara yang telah maju, ini sebagai akibat masih minimnya pengetahuan dan pendidikan masyarakat kita. Mengintensifkan iklan-iklan baik berupa promosi maupun pendekatan personal selling oleh para agen perusahaan kepada masyarakat/calon konsumen.

\section{Pembahasan}

Berdasarkan analisis PLC, dan SWOT, mengenai usaha perusahaan dalam meningkatkan mutu pelayanan demi mencapai kepuasan konsumen yang maksimal diharapkan mendapatkan simpati yang lebih luas dari kalangan masyarakat. Strategi yang digunakan oleh PT. Telkomsel Malang haruslah mempertimbangkan faktor-faktor internal dan eksternal perilaku konsumen dalam menggunakan produk dari PT. Telkomsel. Faktor-faktor tersebut antara lain pertama, motivasi, yang menjadi alasan utama penggunaan kartu selular GSM adalah kebutuhan. Itemnya adalah kebutuhan yang wajib terpenuhi, kebutuhan untuk meningkatkan kreativitas, kebutuhan akan harga diri dalam masyarakat, untuk itu perusahaan harus jeli melihat peluang tersebut, dimana pada masa sekarang telepon selular merupakan kebutuhan komunikasi yang sangat praktis dan ekonomis dan menjadi trend, juga sebagai kebutuhan akan harga diri dalam masyarakat. Karena ada sebagian masyarakat menganggap bahwa telepon selular dan kartu selular adalah teknologi canggih yang ada pada abad ini. Karenanya merupakan kebanggaan tersendiri jika dapat menggunakan 
dan memilikinya. Kedua, persepsi, melihat dari fungsi telepon selular dan kartu selular yang sangat praktis jika digunakan terutama pada kehidupan masyarakat yang selalu terbiasa bergerak dinamis, masyarakat perkotaan yang menganggap waktu sangat berharga, maka kenyamanan dan kompleksitas pemakaian telpon selular ditambah kartu selular sangat dibutuhkan. Karena itu PT. Telkomsel yang sudah memiliki hal tersebut pada kartu selular GSM-nya menimbulkan persepsi pada masyarakat luas. Persepsi tersebut sangat menuntungkan bagi perusahaan.

Ketiga, proses belajar, perubahan perilaku konsumen terjadi sebagai akibat adanya pengalaman yang terjadi dengan adanya interaksi pada lingkungannya. Perubahan tersebut dapat saja terjadi karena pengalaman sendiri, kebiasaan atau pengalaman orang lain. Hal ini sangat berpengaruh pada kelangsungan hidup perusahaan. Jika konsumen sudah mempunyai pengalaman atau kebiasaan yang baik mengenai penggunaan kartu selular dari PT. Telkomsel maka hal tersebut akan sangat menguntungkan. Karena itu perlu adanya peningkatan mutu baik produk maupun pelayanan agar dalam proses belajarnya konsumen mempunyai pengalaman yang baik tentang PT. Telkomsel Malang, sehingga tercipta pula image yang baik bagi perusahaan.

Keempat, sikap, tingkat kemampuan fisik dan mental konsumen dalam pembelian kartu selular GSM perlu ditanggapi. Kemampuan konsumen/calon konsumen untuk menerima keberadaan suatu jenis telpon selular, tingkat kepercayaan konsumen dalam menggunakan kartu selular tersebut mendasari perusahaan dalam mengambil keputusan kartu selular GSM jenis apa yang dibutuhkan oleh konsumen/calon konsumen tersebut.

Kelima, kepribadian, sifat konsumen yang dapat menentukan tanggapan, baik dari diri sendiri maupun dari luar (lingkungan), pengetahuan dari konsumen, perasaan dari hasil pengaruh pengetahuan dan dorongan untuk meniru orang lain dalam berperilaku, sangat berpengaruh terhadap pribadi seseorang dalam mengambil keputusan penggunaan kartu selular GSM apa yang sesuai dengan kepribadiannya.

Keenam, konsep diri, berangkat dari bagaimana cara seseorang memandang dirinya sendiri, maka seorang konsumen akan dapat menentukan merk kartu telpon selular yang paling disukai oleh masing-masing konsumen. 
Konsumen lebih senang berhubungan dengan agen-agen penjual, karena tersebar dimana saja sehingga mudah didapat.

Faktor-faktor yang mempengaruhi konsumen berasal dari lingkungan di sekitar konsumen yang dapat mendorong konsumen melakukan pembelian, antara lain pertama, keluarga, keluarga konsumen/calon konsumen dapat mempengaruhi dalam keputusan pembelian kartu selular GSM tersebut, sebab sebelum mengambil keputusan untuk memilih dan membeli dan membeli kartu selular GSM tentunya konsumen melihat atau berpatokan ataupun bertanya kepada keluarga terlabih dahulu karena keluarga adalah orang yang terdekat dengan konsumen.

Kedua, kelas sosial, perbedaan masyarakat dalam kelas-kelas tertentu secara bertingkat didasarkan atas kekayaan, jabatan dan pendidikan (ilmu pengetehuan) tentunya sangat berpengaruh dalam kehidupan/ calon konsumen. Jika seorang konsumen/calon konsumen berasal dari kelas tertentu, tentunya akan menjadi pangsa pasar yang bagus untuk perusahaan, kemudian perusahaan akan memberikan pilihan tetapi keputusan tetap ada di tangan konsumen.

Ketiga, kelompok panutan, Jika konsumen atau calon konsumen menjadi anggota suatu kelompok, secara tidak langsung pengaruh kelompok tersebut akan menjadi panutan si konsumen. Kelompok tersebut bisa lingkungan (kelompok) kerja, perkumpulan/organisai dan lain-lain. Oleh karena itu sangat baik jika perusahaan juga dapat menanam imej yang baik pada kelompok tersebut.

Keempat, kebudayaan, adat istiadat, norma, nilai-nilai sosial yang berlaku di masyarakat sangat menentukan dalam kehidupan seseorang. Beruntunglah kebudayaan di Indonesia sudah dapat menerima teknologi yang terus berkembang, sehingga masyarakatpun tidak menutup diri untuk hal-hal yang berhubungan dengan kemajuan teknologi.

Jika dilihat, kebutuhan konsumen akan kartu selular sangat beragam. Ada yang dikarenakan komunikasi yang dituju ataupun komunikasi kepada konsumen yang sulit dijangkau, kesibukan yang kompleks di daerah perkotaan, fasilitas dari instansi yang bertujuan memudahkan karyawannya dalam bekerja, pengaruh dari teman/keluarga, dan sebagainya. Dari beragam kebutuhan 
tersebut dapat digambarkan keinginan dan kebutuhan konsumen akan kartu selular GSM. Konsumen tentunya menilai dari harga, kualitas, dan manfaatnya bagi kebutuhannya. Dalam rangka mencapai kepuasan konsumen tersebut tentunya PT. Telkomsel selalu meningkatkan kualitas produk kartu selular GSMnya. Dengan adanya pengembangan jaringan secara agresif dan penambahan fasilitas-fasilitas yang ada pada kartu selular GSM baik Pra Bayar maupun Pasca Bayar PT. Telkomsel selalu melakukan pengembangan/inovasi demi mencapai kepuasan konsumen.

Sebelum melakukan keputusan pembelian tentunya konsumen sudah mendapatkan informasi mengenai kartu selular GSM yang dimaksud. Informasi tersebut dapat berasal dari kerabat, keluarga, perusahaan, media masa, dan lainlain. Setelah itu konsumen dapat mengambil keputusan pembelian dengan melihat/membandingkan dengan beragam kartu selular GSM yang ada, melihat kondisi keuangan yang tersedia, serta menilaidari sumber mana ia mendapatkan kartu selular GSM tersebut. Dalam hal ini perusahaan mempunyai strategi memaksimalkan kepuasan konsumen.

\section{Strategi Perusahaan}

Integrasi ke depan (penyalur), PT. Telkomsel meningkatkan kontrol atas penyalur atau penjualan eceran, dikarenakan banyaknya penyalur atau penjualan yang bermain dengan harga. Pengembangan pasar, perusahaan memperkenalkan produk yang sudah ada ke daerah pemasaran yang baru. Strategi ini mempertimbangkan jaringan distribusi yang dimiliki oleh PT. Telkomsel, juga dari produk PT. Telkomsel yang berkualitas dan harga yang tepat. Disamping itu jika mendapatkan pangsa pasar baru tentunya konsumen akan terus bertambah dengan pasar yang ada belum jenuh.

Pengembangan produk, PT. Telkomsel selalu melakukan inovasi pada produknya, perusahaan memiliki kemampuan dalam Research and Development sedangkan industri yang ada sedang tumbuh, sehingga PT. Telkomsel selalu mendapatkan tempat tersendiri di kalangan konsumen. Pengembangan produk yang baru-baru ini dilakukan oleh PT. Telkomsel dengan menambahkan fasilitas SMS yang ada pada kartu kredit selular GSM pra bayar. 
Perusahaan akan selalu malakukan inovasi-inovasi baru guna mencapai kepuasan konsumen dan mencegah kejenuhan pasar.

Lebih memperkenalkan perusahaan secara keseluruhan sebagai upaya menciptakan Brand Image bagi usaha yang dijalankan. Dalam hal ini perusahaan harus mampu menyajikan keunggulan-keunggulan yang dimiliki oleh perusahaan dengan cara layanan pra bayar dan purna jual promosi, kualitas produk, dan lain-lain yang ditangani dengan baik oleh PT. Telkomsel. Mampu menjaga Brand Image yang selama ini telah tercipta dalam pasar. Meningkatkan sistem kinerja dan produk sesuai dengan perkembangan arus informasi dan teknologi yang ada. Hal ini selain dapat menimbulkan perkembangan lingkungan, juga dapat menimbulkan kesan positif dimata konsumen. Memperbesar jaringan penjualan dan pelayanan dalam rangka mengusai pangsa pasar potensial.

Memperbesar perolehan laba usaha sebagai bagian dari kegiatan dalam mempertahankan posisi perusahaan dengan tidak melupakan kebutuhan dan keinginan konsumen, sehingga perusahaan benar-benar dapat bertanggung jawab dalam memberikan pelayanan kepada masyarakat melalui produkproduknya. Khususnya untuk kartu selular pasca bayar (Kartu Halo) perusahaan mengadakan penjajakan terlebih dahulu atas keadaan ekonomi, kondisi keluarga dan kondisi pribadi sehingga nantinya dapat saling pengertian dalam memberikan kepuasan timbal balik bagi kedua belah pihak.

\section{KESIMPULAN DAN SARAN}

\section{Kesimpulan}

Adapun kesimpulan dari hasil penelitiana adalah sebagai berikut:

1. Lebih memperkenalkan perusahaan secara keseluruhan sebagai upaya menciptakan corporate image bagi usaha yang dijalankan. Dalam hal ini perusahaan harus mampu menyajikan keunggulan-keunggulan yang dimiliki oleh perusahaan dengan cara layanan pra bayar dan purna jual, promosi, kualitas produk, dan lain-lain yang ditangani dengan baik oleh PT. Telkomsel.

2. Mampu menjaga Brand Image yang selama ini telah tercipta dalam pasar. Meningkatkan sistem kinerja dan produk sesuai dengan perkembangan arus 
informasi dan teknologi yang ada. Hal ini selain dapat menimbulkan perkembangan lingkungan, juga dapat menimbulkan kesan positif dimata konsumen. Memperbesar jaringan penjualan dan pelayanan dalam rangka mengusai pangsa pasar potensial.

3. Memperbesar perolehan laba usaha sebagai bagian dari kegiatan dalam mempertahankan posisi perusahaan dengan tidak melupakan kebutuhan dan keinginan konsumen, sehingga perusahaan benar-benar dapat bertanggung jawab dalam memberikan pelayanan kepada masyarakat melalui produkproduknya. Khususnya untuk kartu selular pasca bayar (Kartu Halo) perusahaan mengadakan penjajakan terlebih dahulu atas keadaan ekonomi, kondisi keluarga dan kondisi pribadi sehingga nantinya dapat saling pengertian dalam memberikan kepuasan timbal balik bagi kedua belah pihak.

\section{Saran}

1. Berdasarkan luasnya jangkauan pemasaran dan kemampuan perusahaan didalam memenangkan persaingan dalam industri kartu selular GSM ini maka PT. Telkomsel Malang harus mampu meningkatkan produk dan layanan dengan mengetahui sejauh mana tingkat kepuasan konsumen atas produk dan layanan yang dimiliki oleh perusahaan, sehingga perusahaan mendapatkan respon positif yang lebih luas bagi konsumen/calon konsumen.

2. Perusahaan hendaknya tetap mempertahankan dan terus berusaha meningkatkan teknologi pada produk yang disesuaikan dengasn perkembangan jaman, serta meningkatkan pelayanan yang memuaskan kepada konsumen, sehingga tujuan perusahaan untuk menciptakan image atau citra yang positif dimasyarakat akan tercapai, meskipun dalam kondisiperekonomian yang lesu dan kondisi persaingan yang tajam.

3. Distribusi kartu selular GSM pra bayar yang agak tersendat-sendat dikarenakan berbagai macam sebab sebaiknya lebih diminimalisasikan, salah satunya dengan kebijakan harga dan distribusi chanel yang resmi. Perusahaan dapat bekerja sama dengan perusahaan telepon selular tertentu agar diperoleh pangsa pasar yang lebih luas. 
4. Frekuensi promosi perusahaan kepada kegiatan kemasyarakatan (sosial) lebih ditingkatkan lagi, mengingat tidak seluruh masyarakat tahu fungsi dan manfaat kartu seluler GSM tersebut, sehingga memperluas sehingga memperluas pasar dan menemukan pangsa pasar baru.

5. Kartu selular GSM pasca bayar, agar pasar tidak mengalami kejenuhan maka harus selalu dilakukan promosi secara kontinyu dan meninjau kembali kebijaksanaan tarif pulsa yang digunakan untuk lebih meringankan konsumen yang optimal.

6. Perlu dipertimbangkan faktor-faktor intern dan faktor-faktor ektern yang mempengaruhi perilaku konsumen dalam menggunakan produk dari PT. Telkomsel, menentukan strategi variasi agar tercapai kepuasan yang maximal pada konsumen, menentukan strategi generik, yaitu ekspansi agar pasar potensial lebih terjangkau dan menetapkan posisi perusahaan sebagai perusahaan kartu seluler GSM terkemuka.

\section{DAFTAR PUSTAKA}

Anwar, Saifuddin. 1986. Reliabilitas dan Validitas Interpretasi dan Komputerisasi, Edisi Pertama. Yogyakarta: Liberty.

Bambang, Setyadin. 1995. Analisis Instrumen. Lembaga Penelitian, Institut Keguruan dan Ilmu Pendidikan Malang.

Swastha, Basu DH. 1996. Azas-azas Marketing, Edisi ketiga. Yogyakarta: Penerbit Liberty.

Cravens, David W. 1996. Pemasaran Strategis, Alih bahasa Lina Salim, Edisi ke empat, jilid satu. Jakarta: Penerbit Erlangga.

Emory, William C. 1980. Businnes Research Methods, Revised Edition. Homewoiod Illinois: Richard D. Irwin, Inc.,

Tjiptono, Fandy. 1997. Strategi Pemasaran, Edisi Kedua. Yogyakarta: Penerbit Andi.

Supranto. 1990. Teknik Riset Pemasaran Dan Ramalan Penjualan, Edisi Revisi, Cetakan Pertama. Jakarta: PT Rineka Cipta.

Hadi, Sutrisno. 1994. Metodologi Research, Cetekan ke XIV. Yogyakarta: Andi Offset. 
Kotler, Philip. 1998. Manajemen Pemasaran, Analisis, Perencanaan, Implementasi dan Kontrol, Alih bahasa Hendra teguh dan Rony A. Rusli, Edisi 9, Jilid 1 dan 2. Jakarta: PT Prenhalindo.

Payne, Adrian. 2001. The Essence of Services Marketing, Pemasaran Jasa. Alih bahasa Fandy Tjiptono, Edisi Pertama. Yogyakarta: Penerbit Andi.

Kasali, Rhenald. 1998. Membidik Pasar Indonesia. Segmentasi, Targeting dan Positioning. Jakarta: PT Gramedia Pustaka Utama.

Ries, Al Jack, Trout. 2002. Positioning: The battle for Your Mind. Alih Bahasa Bertha Lucia, Edisi Pertama. Jakarta: Penerbit Salemba Empat.

Sudjana. 1992. Metode Statistika. Edisi kelima. Bandung: Tarsito.

Arikunto, Suharsimi. 1996. Prosedur Penelitian Suatu Pendekatan Praktek. Edisi revisi III. Jakarta: Penerbit PT Rineka Cipta. 